\title{
Factors influential to the acceptance of managerial accounting tools in Tra Vinh's small and medium enterprises
}

\section{Quang Linh Huynh ${ }^{a^{*}}$}

${ }^{\mathrm{a}}$ Ho Chi Minh City University of Food Industry, Vietnam

\begin{tabular}{l}
\hline C H R O N I C L E \\
\hline Article history: \\
Received March 3, 2021 \\
Received in revised format May \\
112021 \\
Accepted June 52021 \\
Available online \\
June 5 2021 \\
\hline Keywords: \\
Managerial accounting \\
Usefulness \\
Environmental uncertainty \\
Corporate governance \\
Organizational interdependence \\
Tra Vinh
\end{tabular}

\section{Introduction}

Managerial accounting tools are commonly regarded as a vital controlling instrument which can provide directors with accounting information for making better business decisions and better using corporate resources. Johnson and Kaplan (1987) contended enterprises necessitate managerial accounting tools for sensible and exact information to effectively control costs, accurately evaluate and to enhance output. Over the last decades, numerous studies on managerial accounting have been conducted in developed countries. Nevertheless, Lin and Yu (2002) found the acceptance of managerial accounting tools in developing countries remains undesirable. Sulaiman et al. (2004) demonstrated a lack of investigative research in Asia including Vietnam and a need to systematically examine the reasons why they have not been employing advanced managerial accounting tools and which factors prevent their acceptance. Because of the important function of managerial accounting tools, enterprises in general and small and medium-sized enterprises (SMEs) in particular, should perceive the importance of managerial accounting tools and try to adopt them in business (Yến \& Nguyên 2020). Although enterprises in Vietnam have perceived the importance of managerial accounting in running enterprises, they have only used a few managerial accounting tools in business. This is consistent with the contingency theory of managerial accounting (Hayes, 1977) which states specific circumstances shape the forms of managerial accounting in business. In other words, the Vietnamese business situation shapes managerial accounting tools used in Vietnam.

\footnotetext{
* Corresponding author

E-mail address: $\underline{\text { linhhq@hufi.edu.vn (Q. L. Huynh) }}$

C 2022 Growing Science Ltd. All rights reserved. doi: 10.5267/j.ac.2021.6.004 
According to the department of planning and investment of Tra Vinh province (2018), SMEs have had a significant position in the economic development of Tra Vinh province, accounting for about $97 \%$ of the total number of enterprises within the province, which play a huge role in creating jobs and increasing incomes for local workers. The report also affirmed that SMEs have small investment capital, but develop widely in urban as well as rural areas, in most industries. SMEs exploit and mobilize potential resources, create opportunities for many people to participate in investment and create a healthier competitive market. Despite playing a vital function in the economic development of Tra Vinh province, SMEs here still face many difficulties in business management; because they still lack effective managerial tools in business, especially managerial accounting tools. This is because managerial accounting is still quite new in Vietnam and has just appeared in Vietnam, starting with the introduction of the Accounting Law on the concept of managerial accounting in 2003; although it has been around for decades in developed economies (Doan et al. 2011). To date, there has been only a little research on managerial accounting tools in Vietnam in general and in Tra Vinh province. Nearly no empirical studies have examined the factors affecting the acceptance of managerial accounting tools in Tra Vinh's small and medium enterprises. Therefore, the aim of this research is to scrutinize the factors affecting the acceptance of managerial accounting tools in Tra Vinh's economic settings. This article contributes to the managerial accounting literature by delivering one of Tra Vinh's perspectives to managerial accounting.

\section{Hypotheses development}

\subsection{Usefulness of Managerial Accounting}

The current research refers to the acceptance of managerial accounting tools as the degree to which a corporation picks and accepts these tools in business. The technology acceptance model (TAM) is employed to explain the usefulness of managerial accounting tools. Based on Albarracin and Shavitt (2018), TAM are based on the theory of reasoned action where the behavior is a function of beliefs of persons about the consequence of their behavior. Davis (1989) referred to the perceived usefulness as the degree to which a person considers the use of a specific tool will improve their working effectiveness. Additionally, Chenhal and Morris (1986) defined the usefulness of managerial accounting tools in terms of scope, timeliness, aggregation, and integration of information. The usefulness of managerial accounting tools for this study is referred to to the extent that managerial accounting tools are perceived useful in controlling business activities. Additionally, Sam et al. (2012) provided evidence on the associations from the usefulness of computerized accounting tools to the acceptance of them in business, which work similarly to managerial accounting tools, where these tools are all functioned to augment organizational effectiveness. Likewise, Huynh (2015) suggested a statistical effect of computerized accounting usefulness on its acceptance. Based on the above-mentioned considerations to the managerial accounting setting, the following hypothesis could be suggested.

\section{$\mathbf{H}_{1}$ : Usefulness of managerial accounting tools influences the acceptance of them in business.}

\subsection{Environmental Uncertainty}

Duncan (1972) refers to environmental uncertainty as a necessary circumstantial factor. This scholar linked environmental uncertainty to customers, suppliers, competitors, social-political issues, and technologies. According to a study of Miles et al. (1978), environmental uncertainty is assessed on the predictability of the business environment facing enterprises. In addition, Jusoh (2010) considered predictability as enterprises' ability to estimate their business environment. For this study, environmental uncertainty is defined as the following variables; namely levels of change of law involved in the enterprise, degrees of technological development, variations of financial markets and labor supplies, degrees of competition for suppliers and customers, and demands and prices of products and/or services. From a project of Pfeffer and Leblebici (1973), when environmental competitiveness becomes more sophisticated, directors' demands for formal tools would be larger. While Chenhall and Morris (1986) examined the impact of environmental uncertainty on the usefulness of managerial accounting tools in business, Etim (2019) provided evidence on the correlation from environmental uncertainty to managerial accounting tools and the findings are in support of this causal linkage. Furthermore, Jusoh (2010) showed environmental uncertainty is significantly interrelated to the usage of economic performance measures. He also regarded the importance of perceived environmental uncertainty as a substitute for external variables to businesses in explaining the acceptance of performance measures. These findings lead to the following hypothesis for this study.

\section{$\mathbf{H}_{2}$ : Environmental uncertainty influences the acceptance of managerial accounting tools in business.}

\subsection{Corporate Governance}

Mayer (1997) regarded corporate governance as methods to confirm the interests of all the stakeholders of enterprises. Moreover, Huynh (2017) defined corporate governance as compositions of directory and supervisory boards as well as the duality of chief executive officers. Managerial tools should be more sophisticated to satisfy the desires of related stakeholders (Lucas, 1997). The perspectives referred to the acceptance of managerial accounting in business as the extent of using them in both the contemporary and customary techniques. Additionally, corporate governance is one of the determinants which boost the acceptance of managerial accounting tools in business. Independent executives with excellent education, experience, and proficiency, when running establishments, prefer to employ the formalization in business (Salvato \& Melin, 2008). In addition, the chance of restatement is lower in enterprises with supervisory and directory boards 
consisting of independent financial directors; nevertheless, higher in enterprises if the chief executive officer is a giant shareholder (Agrawal \& Chadha, 2005). This is because independent executives employ formal supervisory practices to make more realistic statements. Consequently, corporate governance is likely an imperative determinant in boosting the acceptance of managerial accounting tools for running enterprises. Furthermore, Htay and Salman (2013) recommended a causal linkage from corporate governance to the acceptance of managerial accounting tools in business. Likewise, Nyatichi et al. (2020) mentioned that, corporate governance is a driving force leading to the management of earnings in business. Similarly, Huynh (2015) examined a significant link from corporate governance to the acceptance of managerial accounting tools, providing significant evidence where the acceptance of managerial accounting tools is conditional on corporate governance. The abovementioned underpinnings could help to reach the following hypothesis.

\section{$\mathbf{H}_{3}$ : Corporate governance likely affects the acceptance of managerial accounting tools in business.}

\subsection{Organizational Interdependence}

Huynh (2017) indicated organizational interdependence should be evaluated on three levels. Pooled interdependence refers to a condition where each division of the enterprise concentrates a discrete contribution to the whole enterprise and in contrast, it should be helped by the others. Sequential interdependence is a condition where one division of the enterprise desires parts which another division yields out for making its products or services. Reciprocal interdependence is a condition where the productions of one division are inputs of the others. In addition, organizational interdependence is regarded as the exchange of productions occurring among divisions within a firm (Chenhall \& Morris, 1986). They assign organizational interdependence to three degrees (pooled, sequential, and reciprocal) as Thompson's definition. In the current research, organizational interdependence is measured on three extents that are pooled, sequential and reciprocal interdependencies.

Numerous researchers recommended the causal link from organizational interdependence to the acceptance of managerial accounting tools in business. For example, Baumler (1971), regarded organizational interdependence as a vital component in the acceptance of managerial accounting tools in business since subsequential and reciprocal situations require more organization than the pooled situation does. Additionally, Choi (2020) established a vigorous connection from organizational interdependence to the acceptance of managerial tools in business. Ibadin and Imoisili (2010) reconsented that link, indicating organizational interdependence affects the acceptance of managerial accounting tools in business. Furthermore, Gerdin (2005) argued an increase in interdependence leads to a rise in managerial information. Based on the above mentioned arguments, the following hypothesis could be proposed.

\section{$\mathbf{H}_{4}$ : Organizational interdependence determines the acceptance of managerial accounting tools in business.}

\subsection{Organizational Size}

Stephen (1990) showed there is a causal link from organizational size and the acceptance of managerial accounting tools. In addition, Ibadin and Imoisili (2010) indicated organizational size has an impact on the design of managerial accounting tools in business. The design of managerial accounting tools in business is linked to information characteristics, which are scope, timeliness, aggregation, and integration. Therefore, those scholars suggested a causal association from organizational size to the design of managerial accounting tools in business. From Hoque and James (2000), organizational size is found to have a positive relation to the acceptance of managerial accounting tools of balanced scorecard. Jusoh (2010) discovered a positive significant bond from organizational size to the acceptance of managerial accounting tools of innovation measure, indicating higher innovation is related to bigger corporations. Moreover, Wu and Boateng (2010) confirmed the positive effect of organizational size on the changes in the acceptance of managerial accounting tools. Likewise, Nair (2017) showed organizational size has an influence on the acceptance of managerial accounting tools in business, as bigger enterprises enjoy larger resources to accept managerial accounting tools in business and need more sophisticated managerial accounting tools. Huynh (2017) indicated a significant effect of organizational size on the acceptance of managerial accounting tools. On the basis of the abovementioned findings, it could propose the following hypothesis.

H5: Organizational size has a positive impact on the acceptance of managerial accounting tools in business.

\section{Research methodology}

\subsection{Variable measurement}

Acceptance of managerial accounting tools (AMT) is calculated on a five-point Likert scale from never considering, to under application of managerial accounting tools. The measurement was modified from Cinquini et al. (2008). The following are managerial accounting tools: (1) Business budget analysis- AMT1; (2) Activity-based-costing analysisAMT2; (3) Cost volume profit analysis- AMT3; (4) Product pricing- AMT4; (5) Balanced scorecard- AMT5. Usefulness of managerial accounting tools (UMT) is computed on a five-point Likert scale from "Managerial accounting tool is not at all useful" to "Managerial accounting tool is most useful", modified from Chenhall and Morris (1986) and Yousef (2007). The items for UMT are consistent with those of AMT (UMT1 to UMT5). Environmental Uncertainty (EUN) is calculated on a five-point Likert scale ranging from "Business environment is never predictable" to "Business environment is always predictable", which was employed by Chenhall and Morris (1986) and Jusoh (2010). The items for EUN are (1) Legal and tax regulations- EUN1; (2) Technological advances- EUN2; (3) Capital and labor markets- EUN3; (4) Competition for suppliers and customers- EUN4; (5) Demand and prices of products and/or services- EUN5. Corporate governance (COE) is computed on the majority of independent directors (COE1), the majority of independent supervisors (COE2) and the 
duality of chief executive officer (COE3). This measure is adapted from Huynh (2017). Organizational Interdependence $(\mathrm{OIN})$ is evaluated on a three-point Likert scale consisting of three extents of intra-unit workflow integration from pooled, and sequential to reciprocal interdependencies, modified from Huynh (2017). Organizational Size (OSZ) is assessed on three degrees: "small", "medium" and "large", which is modified from to Huynh (2017).

\subsection{Data Collection}

A survey was undertaken in Tra Vinh provinces of Vietnam, and the respondents are directors involved in managerial accounting of enterprises operating in almost all dominant industries in Tra Vinh. There were 347 respondents appropriately completing the questionnaire. These figures satisfy the sample size stipulated by Nunnally (1975).

\section{Results}

To examine the reliability and inside consistency of the scale, the Cronbach's $\alpha$ procedure was employed, and the acceptable levels of the Cronbach's $\alpha$ and KMO are 0.7, the lowest threshold suggested by Nunnally (1975). Only the first four scales require Cronbach's $\alpha$ procedure since each of them has more than two items. The results are exhibited in Table 1 . All the item total correlations are more than the 0.5 value, so they were retained for analyses. The Cronbach's $\alpha$ s all exceed the 0.7 level and the KMOs surpass the 0.7 value; indicating the scales had sufficient internal reliability.

Table 1

Reliability analyses

\begin{tabular}{cccc}
\hline Scale & Cronbach's $\alpha$ & KMO & N of Items \\
\hline AMT & 0.812 & 0.789 & 5 \\
UMT & 0.825 & 0.765 & 5 \\
EUN & 0.892 & 0.758 & 5 \\
COE & 0.875 & 0.801 & 3 \\
\hline
\end{tabular}

To assess the causal links from the factors to the acceptance of managerial accounting tools in business in the research model, the current work applied multiple regression analyses. The results are displayed in Tables $2 \& 3$. As Table 2 shows, $48.8 \%$ of total variation in AMT is explained by Model $1\left(\mathrm{R}^{2}=0.488\right)$. The findings also indicate the model is statistically significant at the $1 \%$ level; so gets a good fit to the data.

Table 2

Model summary

\begin{tabular}{ccccccc}
\hline Model & $\mathrm{R}$ & $\mathrm{R}^{2}$ & $\mathrm{R}^{2}$ change & F Change & $\mathrm{P}_{\text {value }} \mathrm{F}$ Change & Durbin-Watson \\
\hline 1 & .682 & .465 & .465 & 59.389 & .000 & 1.922 \\
\hline
\end{tabular}

The coefficients of Durbin-Watson take the values of 1.922 falling between du and $(4-\mathrm{du})$, which reveals no autocorrelation. In addition, Table 3 indicates that, the coefficient of $\chi 2$ from the Breusch-Pagan test achieves the value of $0.434 \mathrm{with}$ the estimate of $\mathrm{P} \chi 2$ equal to 0.382 that surpasses the $10 \%$ significance level, so indicating no heteroskedasticity. Furthermore, the estimators of VIF all obtain the values less than the 2 lowest thresholds, showing no multicollinearity. Overall, the multiple regression analysis gets the goodness of fit. As Table 3 illustrates, the hypotheses H1, H2, H3, H4 and H5 are supported at the $10 \%$ significance level. UMT and COE affect the acceptance of managerial accounting tools at the $1 \%$ significance level with the coefficients of 0.106 and 0.388 respectively, whereas EUN and OSZ affect the acceptance of managerial accounting tools at the 5\% significance level with the coefficients of 0.085 and 0.093 , respectively. OIN influences the acceptance of managerial accounting tools at the $10 \%$ significance level with the 0.068 coefficient. The findings mean that, $\mathrm{COE}$ and UMT are two factors that most strongly determine the acceptance of managerial accounting tools in business. OIN is the weakest determinant of the acceptance of managerial accounting tools.

Table 3

Causal linkages

\begin{tabular}{|c|c|c|c|c|c|c|c|c|c|}
\hline Model & Explained & Independent & $\beta$ & Std. Error & $\mathrm{t}$ & $\mathrm{P}_{\text {value }}$ & VIF & $\chi^{2}$ & $\mathrm{P}_{\text {value }}$ \\
\hline \multirow{6}{*}{1} & \multirow{6}{*}{ AMT } & Constant & 3.781 & .130 & 29.006 & .000 & & \multirow{6}{*}{.434} & \multirow{6}{*}{.382} \\
\hline & & UMT & .106 & .033 & 3.226 & .001 & 1.105 & & \\
\hline & & EUN & .085 & .034 & 2.487 & .013 & 1.159 & & \\
\hline & & $\mathrm{COE}$ & .388 & .037 & 10.389 & .000 & 1.372 & & \\
\hline & & OIN & .068 & .041 & 1.676 & .095 & 1.628 & & \\
\hline & & OSZ & .093 & .044 & 2.124 & .034 & 1.928 & & \\
\hline
\end{tabular}




\section{Conclusion}

From the results of this paper, some implications are evident for those responsible for managerial accounting. As the empirical results show, the perceived usefulness of managerial accounting tools positively impacts the accepting level of managerial accounting tools in business. When directors perceive a tool of managerial accounting useful to their business, they likely accept it, which was already reported in previous studies.

In addition, the empirical findings also indicate, when an enterprise operates in a highly uncertain business environment or/and interdependence between divisions within the firm rises, its directors incline to perceive managerial accounting tools more useful in running business. Therefore, they more likely accept managerial accounting tools in business. These outcomes are consistent with the previous findings where an uncertain business environment enables directors to require more exact information provided by managerial accounting tools, so that they could successfully run their business.

Furthermore, the results reveal that corporate governance puts statistical influences on the acceptance of managerial accounting tools in business. The evidence on a positive association from organizational interdependence to the acceptance of managerial accounting tools in business is also provided. Additionally, if organizational size is larger, managerial accounting tools are considered necessary to be accepted in business. The research findings of the current article are significant to directors and those involved in managerial accounting. Tra Vinh's business environment is considerably changing because its economy is substantially developing and laws involving business are still being modified. As the findings reveal, the structure of corporate governance is the strongest determinant of the acceptance of managerial accounting tools in business. The second strongest determinant belongs to the usefulness of managerial accounting tools. Therefore, enterprises in Tra Vinh province of Vietnam should pay more attention to their corporate governance and try to enhance their perception on the usefulness of managerial accounting tools, so that they could accept managerial accounting tools. Therefore, they can gain competitive advantages that lead to the highest possible effectiveness.

\section{References}

Agrawal, A., \& Chadha, S. (2005). Corporate governance and accounting scandals. The Journal of Law and Economics, $48(2), 371-406$.

Albarracin, D., \& Shavitt, S. (2018). Attitudes and attitude change. Annual Review of Psychology, 69, $299-327$.

Baumler, J.V. (1971). Defined criteria of performance in organizational control. Administrative Science Quarterly, 16(3), 340-350.

Chenhall, R.H., \& Morris, D. (1986). The impact of structure, environment, and interdependence on the perceived usefulness of management accounting systems. Accounting Review, 61(1), 16-35.

Choi, J.W. (2020). Studying "and": A perspective on studying the interdependence between management control practices. Accounting, Organizations and Society, 86, 101188.

Cinquini, L., Collini, P., Marelli, A., \& Tenucci, A. (2008). An exploration of the factors affecting the diffusion of advanced costing techniques: a comparative analysis of two surveys (1996-2005). The 31st Annual Congress of the European Accounting Association Campus of the Erasmus University, Rotterdam, Holland.

Davis, F.D. (1989). Perceived usefulness, perceived ease of use, and user acceptance of information technology. Management Information System Quarterly, 13(3), 319-340.

Doan N.P.A., Nguyen D.T., \& Mia L. (2011) Western management accounting practices in Vietnamese enterprises: Adoption and perceived benefits. Pacific Accounting Review, 23(2), 142 - 164.

Duncan, R.B. (1972). Characteristics of organizational environments and perceived environmental uncertainty. Administrative Science Quarterly, 17(3), 313-327.

Etim, E.O. (2019). Management accounting system, perceived environmental uncertainty and corporate performance of the Nigerian breweries sector. Archives of Business Research (ABR), 7(7), 255-268.

Gerdin, J. (2005). The impact of departmental interdependencies and management accounting system use on subunit performance. European Accounting Review, 14(2), 297-327.

Hayes D.C. (1977) Contingency theory of management accounting. The Accounting Review, 52(1), 22-39.

Hoque, Z., \& James, W. (2000). Linking balanced scorecard measures to size and market factors: impact on organizational performance. Journal of Management Accounting Research, 12(1), 1-17.

Htay, S. N. N., \& Salman, S. A. (2013). Balanced score card approach for Better Shari'ah corporate governance. American Journal of Applied Sciences, 10(12), 1553.

Huynh, Q.L. (2015). Analyzing the role of computerized accounting usefulness with quantile regression. American Journal of Applied Sciences, 12(9), 669-678.

Huynh, Q.L. (2015). The mutual relationship between corporate governance and management accounting: Which occurs first? American Journal of Applied Sciences, 12(6), 403-410.

Huynh, Q.L. (2017). Corporate governance on the corporate characteristics- managerial accounting link. American Journal of Applied Sciences, 14(5), 560-568.

Ibadin, P.O. \& Olumhense Imoisili, O. (2010) Organiaztion contexts and management accounting system design: Empirical evidence from Nigeria. International Journal of Current Research, 10, 064-073.

Johnson, H.T., \& Kaplan, R.S. (1987). The rise and fall of management accounting. Strategic Finance, 68(7), $22-22$.

Jusoh, R. (2010). The influence of perceived environmental uncertainty, firm size, and strategy on multiple performance measures usage. African Journal of Business Management, 4(10), 1972-1984. 
Lin, Z.J., \& Yu Z. (2002) Responsibility cost control system in China: the Han Dan experience. Asia Pacific Business Review, 9(1), 59-78.

Lucas, M. (1997). Standard costing and its role in today's manufacturing environment. Management Accounting: Magazine for Chartered Management Accountants, 75(4), 32-34.

Mayer, C. (1997). Corporate governance, competition, and performance. Journal of Law and Society, 24(1), $152-176$.

Miles, R.E., Snow, C.C., Meyer, A.D., \& Coleman Jr.H.J. (1978). Organizational strategy, structure, and process. Academy of Management Review, 3(3), 546-562.

Nair, S. (2017). Factors affecting management accounting practices in Malaysia. International Journal of Business and Management, 12(10), 177-184.

Nunnally, J.C. (1975). Psychometric theory-25 years ago and now. Educational Researcher, 4(10), 7-21.

Nyatichi, V., Iraya, C., Mwangi, M., \& Njihia, J. (2020). Corporate governance, firm characteristics and earnings management of companies listed at Nairobi Securities Exchange. DBA Africa Management Review, 10(4), 54-70.

Pfeffer, J., \& Leblebici, H. (1973). The effect of competition on some dimensions of organizational structure. Social Forces, $52(2), 268-279$

Salvato, C., \& Melin, L. (2008). Creating value across generations in family-controlled businesses: The role of family social capital. Family Business Review, 21(3), 259-276.

Sam, M.F.M., Hoshino, Y., \& Tahir M.N.H. (2012). The adoption of computerized accounting system in small medium enterprises in Melaka, Malaysia. International Journal of Business and Management, 7(18), 13-25.

Stephen, R.P. (1990). Organizational theory: Structure, design, and applications. Prentice-Hall, USA.

Sulaiman, M., Ahmad, N.N., \& Alwi, N. (2004). Management accounting practices in selected Asian countries: a review of the literature. Managerial Auditing Journal, 19(4), 493-508.

Wu, J., \& Boateng, A. (2010). Factors influencing changes in Chinese management accounting practices. Journal of Change Management, 10(3), 315-329.

Yến, T.T., \& Nguyên, N.P. (2020). Vai trò của kế toán quản trị trong việc thúc đẩy học tập tổ chức, năng lực đổi mới và kết quả hoạt động kinh doanh ở các doanh nghiệp tại Việt Nam. Tạp chí Nghiên cứu Kinh tế và Kinh doanh Châu Á, 30(5), 61-88 (In Vietnamese)

Yousef, D.A. (2007). Status of yield management in service organizations in the United Arab Emirates: Results of a survey. Journal of Business and Public Affairs, 1(2), 1-9

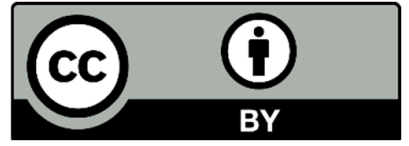

(C) 2022 by the authors; licensee Growing Science, Canada. This is an open access article distributed under the terms and conditions of the Creative Commons Attribution (CC-BY) license (http://creativecommons.org/licenses/by/4.0/). 